\title{
Effects of the Harvest Stage of Maize Hybrids on the Chemical Composition of Plant Fractions: An Analysis of the Different Types of Silage
}

\author{
Egon Henrique Horst ${ }^{1,2, *(\mathbb{D})}$, Valter Harry Bumbieris Junior ${ }^{1} \mathbb{D}$, Mikael Neumann ${ }^{3}$ and Secundino López ${ }^{2,4, *(\mathbb{D})}$ \\ 1 Department of Animal Science, State University of Londrina, Londrina 86057-970, Brazil; jrbumbieris@uel.br \\ 2 Departamento de Producción Animal, Universidad de León, 24007 León, Spain \\ 3 Department of Veterinarian Medicine, Parana Midwestern State University, Guarapuava 85040-167, Brazil; \\ neumann.mikael@hotmail.com \\ 4 Instituto de Ganadería de Montaña (IGM), CSIC-Universidad de León, Finca Marzanas s/n, \\ 24346 Grulleros, Spain \\ * Correspondence: egonhh@yahoo.com.br (E.H.H.); s.lopez@unileon.es (S.L.)
}

\section{check for} updates

Citation: Horst, E.H.; Bumbieris Junior, V.H.; Neumann, M.; López, S. Effects of the Harvest Stage of Maize Hybrids on the Chemical Composition of Plant Fractions: An Analysis of the Different Types of Silage. Agriculture 2021, 11, 786 https://doi.org/10.3390/ agriculture11080786

Academic Editors: Elisabet Nadeau, Horst Auerbach and João Daniel

Received: 10 June 2021

Accepted: 16 August 2021

Published: 17 August 2021

Publisher's Note: MDPI stays neutral with regard to jurisdictional claims in published maps and institutional affiliations.

Copyright: (c) 2021 by the authors. Licensee MDPI, Basel, Switzerland. This article is an open access article distributed under the terms and conditions of the Creative Commons Attribution (CC BY) license (https:// creativecommons.org/licenses/by/ $4.0 /)$.

\begin{abstract}
The chemical composition of plant components of three maize hybrids harvested at the beginning of six reproductive stages of maturity was compared. The hybrids evaluated included Maximus VIP3, Defender VIP and Feroz VIP, which were evaluated at each of following stages: R1 (grain formation), R2 (milky grain), R3 (pasty grain), R4 (floury grain), R5 (hard grain) and R6 (ripe grain). The advancement in maturation was linearly related to the crude protein (CP) content of the stem, whole plant, and leaves, and there was a difference among the hybrids. Between R4 and R5 stages, Maximus and Defender presented the highest CP contents for husk (6.58 and 5.42\% for Maximus; 5.54 and 5.17\% for Defender). The neutral detergent fiber (NDF) of the leaves showed a quadratic relationship with the advancement of maturation but did not differ among the hybrids. For all the hybrids, the NDF content in the husk and cobs increased linearly during the reproductive stages ( $>77$ and $78 \%$, respectively, for the three hybrids in R6). Defender had the lowest NDF content of the cob in R3. The acid detergent lignin contents did not differ among stages in the stems, and showed a linear decrease throughout the whole plant, though the contents did not differ among the hybrids. Due to the differences observed, recommendations for harvest based on the maturity stage for each hybrid should be taken into consideration. There seems to be no important distinction among hybrids for harvesting and use of straw. Despite the reduction in grain yield, an early harvest for earlage or snaplage can provide lower lignin content in husk and cob, as well as higher protein content in the husk, favoring the nutritional value of the vegetative fraction (husk and/or cob).
\end{abstract}

Keywords: corn silage; earlage; lignin; snaplage; straw

\section{Introduction}

In addition to whole-plant silage, which is widely used in various regions of the world, the cultivation of maize (Zea mays L.) also allows other forms that are not commonly used, such as earlage, snaplage, and high-moisture grain, and even the use of stover from the harvested plants and dry or moist grain. Due to this range of possibilities, it is important that cultivated hybrids provide the quality of all the fractions involved so that they can be used for specific needs [1].

Numerous studies have evaluated the nutritive value of maize hybrids at different harvest times to produce whole plant silage [2-5], but the same answers on the other forms of storage mentioned are scarce in the literature. Therefore, obtaining data about the nutritional differences in the maize plant fractions in addition to the grain (cob in earlage production; husk and cob in snaplage production; stem and leaves for use as stover) at different harvest times is essential to improve existing concepts. 
In one of the few published studies, Ferraretto et al. [6] examined the effects of the harvest time on the nutritional and fermentative quality of earlage, with better results obtained at the beginning of the black line formation. On the other hand, maize harvested for snaplage production requires a high moisture content to increase the rate and extent of ruminal digestibility [7]. However, advancing maturity affects the fermentation and aerobic stability of snaplage due to the reduction in sugar content, so the ideal harvest time is between $60-70 \%$ DM of the ear [8]. For these two specific forms of harvest, the importance of grain quality seems to be limited [9] as husk and cobs are relatively low-nutritive fractions but constitute a significant proportion of the plant.

The maturity stage has a great impact on the different fractions of the plant, and this can influence the nutritional value of feedstuffs derived from these fractions. Previous studies have shown that the nutritive value is highly dependent on the hybrid cropped [10] and on the plant maturity at harvest [11]. Hetta et al. [12] observed a significant negative correlation between the proportion of non-grain fractions (stem, leaves and cob) and organic matter digestibility and starch content of three maize hybrids, whereas these fractions were positively correlated with protein content.

Maize plants at maturity present an average of $45.9 \%$ grain, $27.5 \%$ stalk, $11.4 \%$ leaves, $8.2 \% \mathrm{cob}$, and $7.0 \%$ of husk, according to Lardy and Anderson [13], but variations among hybrids are often observed. Stem, leaves, husk and cobs are important by-products of maize harvest. For each kilogram of dry grain produced, approximately $0.50 \mathrm{~kg}$ of stem and $0.22 \mathrm{~kg}$ of leaves are generated on DM basis [14]. Currently, the use of these residues is rather limited, due either to their low nutritional quality, competition for use as organic matter for the soil, or the difficulty in collecting them [15]. In any case, this material can be an important feed source in poor regions.

We hypothesized that different maize hybrids advance in maturity inconsistently in the chemical composition of their fractions, and to elucidate the effects of each component of the plant on different forms of silage, the present investigation aims at answering whether the plant fractions among maize hybrids with contrasting maturity differ in chemical parameters.

\section{Materials and Methods}

The experiment was carried out in the Agricultural and Environmental Sciences Sector of the Parana Midwestern State University (UNICENTRO) in Guarapuava, Paraná, Brazil, located at $25^{\circ} 23^{\prime} 02^{\prime \prime} \mathrm{S}$ and $51^{\circ} 29^{\prime} 43^{\prime \prime} \mathrm{W}$. Maize (Zea mays L.) plants were sown in the first half of October under a no-tillage system. At sowing, the spacing between rows was $50 \mathrm{~cm}$, the sowing depth was approximately $4 \mathrm{~cm}$, and the seed distribution per linear meter aimed for a final density of 65,000 plants ha ${ }^{-1}$. The basic fertilizer consisted of $500 \mathrm{~kg} \mathrm{ha}^{-1}$ applied via NPK fertilizer whose formulation was $8 \%, 20 \%$ and $20 \%$ of N, $\mathrm{P}_{2} \mathrm{O}_{5}$ and $\mathrm{K}_{2} \mathrm{O}$, respectively, and urea at a dose of $400 \mathrm{~kg} \mathrm{ha}^{-1}(180 \mathrm{~kg}$ of $\mathrm{N}$ per ha) was applied between the vegetative stage during which there were 4 to 6 fully expanded leaves (V4 and V6, respectively).

Three maize hybrids were evaluated: Maximus VIP3, Defender VIP and Feroz VIP (Syngenta ${ }^{\circledR}$ ), which were single, triple and double hybrids, respectively. The experimental design used was a randomized block design with two factors (hybrid and stage), with three maize hybrids which were harvested at six maturity stages, resulting in 18 treatments with four replications. Each plot of each of the blocks contained 100 rows and was $50 \mathrm{~m}$ in length, and the useful area considered was the 90 central rows, also disregarding the initial and final $5 \mathrm{~m}$ of the block in the direction of sowing.

For chemical analysis, the maize plants from different hybrids were harvested successively at the beginning of the reproductive phases following determinations by Ritchie et al. [16]: R1 (grain formation), R2 (milky grain), R3 (pasty grain), R4 (floury grain), R5 (hard grain) and R6 (ripe grain). When any style-stigma was visible outside the husk, it was interpreted as the beginning of the R1 stage. In the R2 stage, the grains were white on the outside and resembled a bubble in their shape. The grains in the R3 stage had an external yellow color 
and the internal fluid was milky to pasty. At the beginning of stage R4, the milky internal fluid becomes thicker, reaching a pasty consistency. In stage R5, all or almost all grains are floury-hard. In the R6 stage, the formation of the black layer progressively starts from the grains at the tip of the ear.

In each evaluation, ten whole plants in the useful area of each plot were harvested and manually cut to a height of $20 \mathrm{~cm}$ from the soil using the triple pairing method, where plants were marked with ribbons at harvest, allowing similar plants to be harvested at later stage. After harvesting, the plants were taken to the laboratory and divided into their different components: stem, leaves, husk, cobs and straw. The straw corresponds to the vegetative fraction without the presence of grains, which were removed carefully to avoid damage to the ear. The growth characteristics, proportions of each fraction in the plant and its respective dry matter content can be found in a previous study [17].

First, the whole plant and its fraction were roughly chopped with knives and then transferred to a forced-air oven at $55{ }^{\circ} \mathrm{C}$ for partial drying for $72 \mathrm{~h}$. The samples were subsequently ground in a Wiley mill with a $1 \mathrm{~mm}$ mesh sieve. The pre-dried and ground samples were then analyzed for their total dry matter in an oven at $105^{\circ} \mathrm{C}$ for $4 \mathrm{~h}$. The crude protein $(\mathrm{CP})$ content was determined by the micro-Kjeldahl method according to the methodology described by the AOAC [18]. The content of neutral detergent fiber (aNDF) was obtained using thermostable $\alpha$-amylase without the use of sodium sulfite. The contents of acid detergent fiber (ADF) and acid detergent lignin (ADL) were subsequently determined according to the methods of Goering and Van Soest [19], and hemicellulose was estimated by the difference between the NDF and ADF.

The data were subjected to the Shapiro-Wilk and Bartlett tests to verify the assumptions of normality and homogeneity of variance, respectively. Once these assumptions were met, the data were analyzed using the General linear model procedure (PROC GLM) and subjected to both analysis of variance (ANOVA) and the Tukey test to compare multiple means at $5 \%$ significance by the SAS program (see 9.2; SAS Institute Inc., Cary, NC, USA) according to the following statistical model:

$$
Y_{i j k}=\mu+\alpha_{i}+\beta_{j}+\gamma_{i j}+\delta_{k}+\varepsilon_{i j k}
$$

The variables of the equation are as follows: $Y_{i j k}=$ variable response related to hybrid $i$ at stage $j$ in block $k ; \mu=$ overall average; $\alpha_{i}=$ effect of hybrid $i(i=1,2,3) ; \beta_{j}=$ effect of stage $j(j=1,2,3,4,5,6) ; \gamma_{i j}=$ effect of the interaction of hybrid $i$ with stage $j ; \delta_{k}=$ effect of block $k(k=1,2,3,4)$; and $\varepsilon_{i j k}=$ random error associated with each $Y_{i j k}$ observation.

Parameters that did not differ among hybrids but differed among maturity stages were submitted to polynomial regression analysis considering the variable days after emergence-DAE (72-145 days)—using the regression procedure (PROC REG).

The Milk2006 model, developed by Shaver and Lauer [20], was used to estimate the milk production of each hybrid in stages R4, R5 and R6 based on the chemical composition and in vitro digestibility. Samples from stages R1, R2 and R3 were not subjected to this model due to the low concentration of available starch. The Milk2006 model uses current information and has user-defined input flexibility for these forecasts.

\section{Results}

The data in Table 1 show the $p$-values for the influence of the hybrid $(\mathrm{H})$, the maturation stage $(\mathrm{S})$, and the interaction between them $(\mathrm{H} \times \mathrm{S})$, with dispersion measures, for chemical composition for each fraction of the plant. 
Table 1. Level of statistical significance ( $p$-values) of the effects of hybrid $(\mathrm{H})$ and plant maturity stage at harvest $(\mathrm{S})$ on the chemical composition of the whole plant and fractions of the maize plant.

\begin{tabular}{|c|c|c|c|c|c|}
\hline & $\mathrm{CP}$ & NDF & ADF & ADL & HEM \\
\hline & & & Stem & & \\
\hline Hybrid (H) & 0.101 & $<0.001$ & $<0.001$ & $<0.001$ & $<0.001$ \\
\hline Stage $(S)$ & $<0.001$ & $<0.001$ & $<0.001$ & 0.002 & $<0.001$ \\
\hline $\mathrm{H} \times \mathrm{S}$ & 0.001 & $<0.001$ & $<0.001$ & 0.037 & 0.023 \\
\hline \multirow[t]{2}{*}{ SEM } & 0.100 & 0.246 & 0.238 & 0.177 & 0.296 \\
\hline & & & Leaves & & \\
\hline Hybrid (H) & $<0.001$ & 0.220 & $<0.001$ & $<0.001$ & $<0.001$ \\
\hline Stage (S) & $<0.001$ & $<0.001$ & 0.038 & 0.001 & 0.109 \\
\hline $\mathrm{H} \times \mathrm{S}$ & $<0.001$ & $<0.001$ & 0.180 & $<0.001$ & 0.010 \\
\hline \multirow[t]{2}{*}{ SEM } & 0.133 & 0.219 & 0.213 & 0.177 & 0.297 \\
\hline & & & Husk & & \\
\hline Hybrid (H) & $<0.001$ & $<0.001$ & $<0.001$ & $<0.001$ & $<0.001$ \\
\hline Stage (S) & $<0.001$ & $<0.001$ & $<0.001$ & 0.001 & $<0.001$ \\
\hline $\mathrm{H} \times \mathrm{S}$ & $<0.001$ & $<0.001$ & $<0.001$ & $<0.001$ & $<0.001$ \\
\hline \multirow[t]{2}{*}{ SEM } & 0.135 & 0.235 & 0.217 & 0.177 & 0.242 \\
\hline & & & Cob & & \\
\hline Hybrid (H) & $<0.001$ & $<0.001$ & $<0.001$ & $<0.001$ & $<0.001$ \\
\hline Stage (S) & $<0.001$ & $<0.001$ & $<0.001$ & $<0.001$ & $<0.001$ \\
\hline $\mathrm{H} \times \mathrm{S}$ & $<0.001$ & $<0.001$ & $<0.001$ & $<0.001$ & $<0.001$ \\
\hline \multirow[t]{2}{*}{ SEM } & 0.139 & 0.250 & 0.180 & 0.179 & 0.256 \\
\hline & & & Whole plant & & \\
\hline Hybrid (H) & 0.104 & $<0.001$ & 0.034 & 0.080 & $<0.001$ \\
\hline Stage (S) & $<0.001$ & $<0.001$ & $<0.001$ & $<0.001$ & $<0.001$ \\
\hline $\mathrm{H} \times \mathrm{S}$ & 0.010 & $<0.001$ & $<0.001$ & 0.102 & $<0.001$ \\
\hline \multirow[t]{2}{*}{ SEM } & 0.179 & 0.248 & 0.239 & 0.153 & 0.468 \\
\hline & & & Straw & & \\
\hline Hybrid (H) & 0.129 & 0.452 & 0.859 & 0.012 & 0.022 \\
\hline Stage (S) & $<0.001$ & $<0.001$ & 0.004 & 0.065 & $<0.001$ \\
\hline $\mathrm{H} \times \mathrm{S}$ & $<0.001$ & 0.064 & $<0.001$ & 0.018 & $<0.001$ \\
\hline SEM & 0.149 & 0.407 & 0.237 & 0.155 & 0.351 \\
\hline
\end{tabular}

$\mathrm{SEM}=$ Standard error of the mean for $\mathrm{H} \times \mathrm{S}$; Straw = vegetative fraction without the presence of grains.

Without any difference among hybrids, the CP content of the stems decreased with the advancement of each stage of maturation (Table 2). In the initial two stages and in R6, the highest CP content of the leaves was observed for the Maximus hybrid; this content was also higher in R3 and R4 together with Defender. The decrease in CP differed from each hybrid as maturation progressed, with Defender showing a decrease $(p<0.05)$ in R5 only, while Maximus presented a decrease since the initial maturation advanced. Similar behavior during the stages occurred for the husk, with the Feroz hybrid having the highest $\mathrm{CP}$ content $(p<0.05)$ in the two initial stages and the lowest content in all the subsequent stages.

The CP content of the cobs in R3 was reduced by more than half the value obtained in R2. The Maximus and Defender hybrids had the lowest values in R4, while Feroz showed a linear reduction until the R6 stage. The analysis of the whole plant showed a decrease with no difference detected after stage R4. Similar behavior was observed for straw, where the Feroz hybrid maintained a high CP content up to R3 $(p<0.05)$, but its content was lower than that in Maximus and Defender in R6. 
Table 2. Crude protein (\% of DM) of the whole plant and the fractions of three maize hybrids harvested at the beginning of the six reproductive stages of maturity.

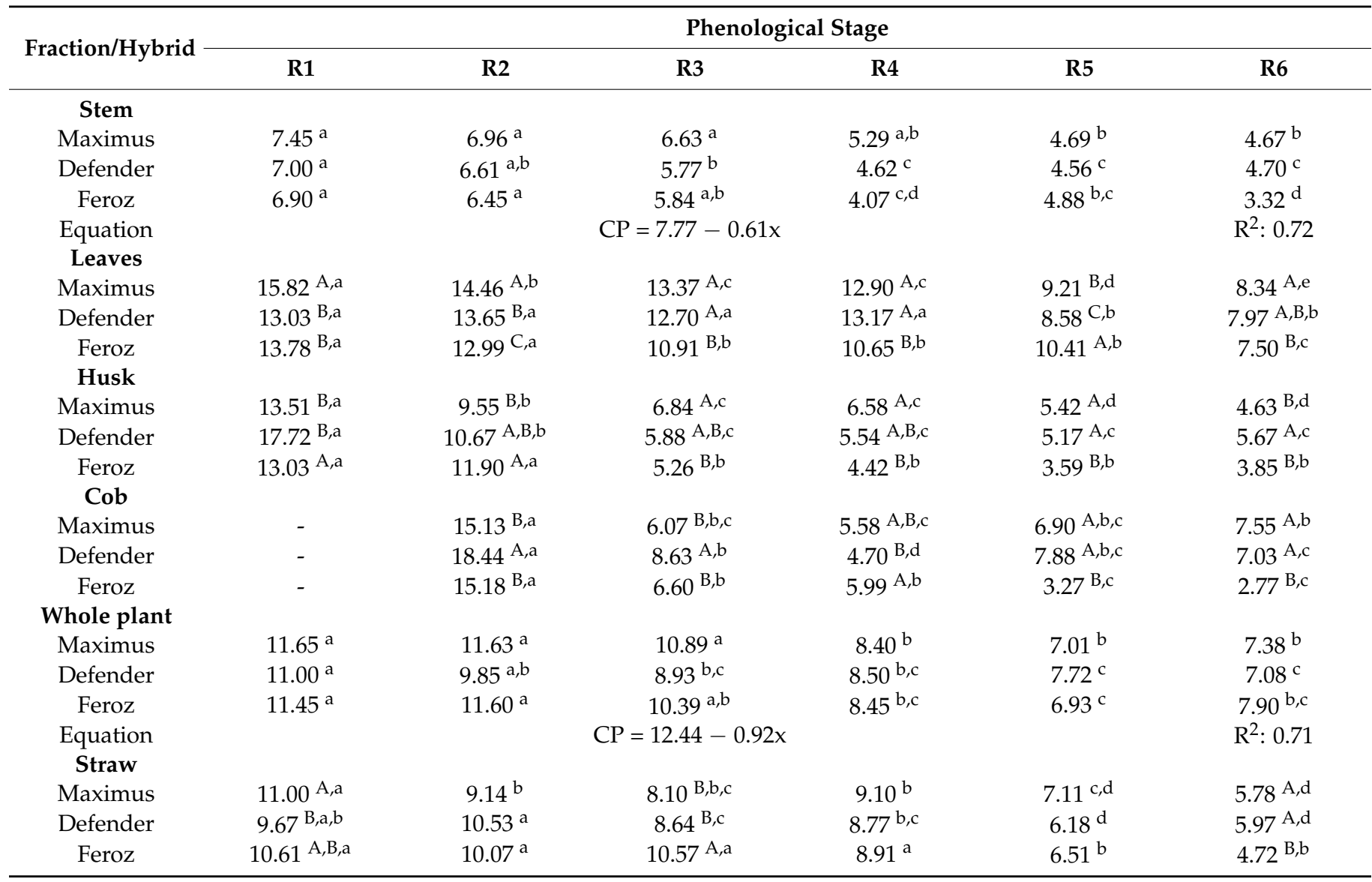

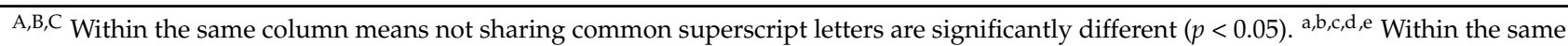
row means not sharing common superscript letters are significantly different $(p<0.05) \cdot \mathrm{x}=$ days after emergency (DAE). Straw $=$ vegetative fraction without the presence of grains.

The NDF contents of the stems (Table 3) differed among hybrids in five stages, but no pattern among them was observed, with Maximus presenting a lower content in R3 to R6 compared to R1 and R2. Defender had the lowest content in R1, and Feroz had the lowest content in R6. The NDF content of the leaves showed an unstable behavior, ranging from $62.84 \%$ for Defender in R1 to $69.95 \%$ for Maximus in R2.

The husk showed an increase in NDF content with the advancement of maturation for the three hybrids; there was no difference among them after the R4 stage. In the first two stages, the Feroz hybrid showed the highest values, but did not differ from the value of Defender in R3. The same trend can be observed for the cobs, with the highest values recorded for Feroz in R5 and R6. This increase in NDF contents with advancing maturity occurred at different rates, resulting in inconsistent differences among hybrids within the maturity stage.

For the Defender hybrids, the highest contents of NDF in the whole plant were detected in the three initial stages, and the lowest values were detected in R5 and R6. Compared with the other two hybrids, the Feroz hybrid showed its highest NDF content $(p<0.05)$ in the R5 stage. The NDF content of straw did not differ among the hybrids and showed inconsistent values for the maturation stage, with a tendency to increase in the final two stages. 
Table 3. Neutral detergent fiber (\% DM) of the whole plant and the fractions of three maize hybrids harvested at the beginning of the six reproductive stages of maturity.

\begin{tabular}{|c|c|c|c|c|c|c|}
\hline \multirow{2}{*}{ Fraction/Hybrid } & \multicolumn{6}{|c|}{ Phenological Stage } \\
\hline & R1 & $\mathbf{R} 2$ & R3 & R4 & R5 & R6 \\
\hline \multicolumn{7}{|l|}{ Stem } \\
\hline Maximus & $73.08^{\mathrm{A}, \mathrm{a}}$ & $71.62^{a}$ & $65.98^{B, c}$ & $67.45^{\mathrm{B}, \mathrm{b}, \mathrm{c}}$ & $67.90^{\mathrm{B}, \mathrm{b}, \mathrm{c}}$ & $68.60^{\mathrm{B}, \mathrm{b}}$ \\
\hline Defender & $70.69^{\mathrm{B}, \mathrm{b}}$ & $70.68^{b}$ & $66.97^{\mathrm{A}, \mathrm{B}, \mathrm{c}}$ & $70.27^{\mathrm{A}, \mathrm{b}, \mathrm{c}}$ & $72.09 \mathrm{~A}, \mathrm{a}, \mathrm{b}$ & $75.29 \mathrm{~A}, \mathrm{a}$ \\
\hline Feroz & $71.22^{\mathrm{A}, \mathrm{B}, \mathrm{a}}$ & $70.63^{a, b}$ & $69.76^{\mathrm{A}, \mathrm{a}, \mathrm{b}}$ & $68.43^{\mathrm{A}, \mathrm{B}, \mathrm{a}, \mathrm{b}}$ & $67.70 \mathrm{C}, \mathrm{b}$ & $62.49^{C, c}$ \\
\hline \multicolumn{7}{|l|}{ Leaves } \\
\hline Maximus & $65.32^{c}$ & $69.95^{a}$ & $67.94^{\mathrm{a}, \mathrm{b}}$ & $66.03^{b, c}$ & $64.75^{c}$ & $64.56^{c}$ \\
\hline Defender & $62.84^{\mathrm{b}}$ & $66.33^{a}$ & $63.05^{b}$ & $63.80^{a, b}$ & $63.91^{\mathrm{a}, \mathrm{b}}$ & $64.59^{a, b}$ \\
\hline Feroz & 63.38 & 65.58 & 64.59 & 65.42 & 65.09 & 65.11 \\
\hline $\begin{array}{c}\text { Equation } \\
\text { Husk }\end{array}$ & \multicolumn{5}{|c|}{$\mathrm{NDF}=63.82+1.14 \mathrm{x}-0.18 \mathrm{x}^{2}$} & $R^{2}: 0.60$ \\
\hline Maximus & $56.90^{\mathrm{B}, \mathrm{f}}$ & $61.25^{\mathrm{B}, \mathrm{e}}$ & $64.19^{\mathrm{B}, \mathrm{d}}$ & $70.16^{c}$ & $76.36^{b}$ & $78.83^{\mathrm{a}}$ \\
\hline Defender & $47.92^{C, d}$ & $60.80^{\mathrm{B}, \mathrm{c}}$ & $67.75^{\mathrm{A}, \mathrm{b}}$ & $68.56^{\mathrm{b}}$ & $77.02^{\mathrm{a}}$ & $78.31^{\mathrm{a}}$ \\
\hline Feroz & $62.63^{\mathrm{A}, \mathrm{c}}$ & $63.32^{\mathrm{A}, \mathrm{c}}$ & $68.07^{\mathrm{A}, \mathrm{b}}$ & $69.92^{b}$ & $77.82^{a}$ & $77.79^{a}$ \\
\hline Cob & & & & & & \\
\hline Maximus & - & $45.24^{\mathrm{A}, \mathrm{e}}$ & $66.52^{\mathrm{B}, \mathrm{d}}$ & $70.09^{c}$ & $76.02 \mathrm{~A}, \mathrm{~B}, \mathrm{~b}$ & $80.37^{\mathrm{A}, \mathrm{B}, \mathrm{a}}$ \\
\hline Defender & - & $36.03^{\mathrm{B}, \mathrm{e}}$ & $63.00 \mathrm{C}, \mathrm{d}$ & $69.17^{c}$ & $74.20^{\mathrm{B}, \mathrm{b}}$ & $78.39^{\mathrm{B}, \mathrm{a}}$ \\
\hline Feroz & - & $35.27^{\mathrm{B}, \mathrm{d}}$ & $69.98^{\mathrm{A}, \mathrm{c}}$ & $70.77^{c}$ & $77.67^{\mathrm{A}, \mathrm{b}}$ & $81.80^{\mathrm{A}, \mathrm{a}}$ \\
\hline \multicolumn{7}{|l|}{ Whole plant } \\
\hline Maximus & $53.53^{\mathrm{A}, \mathrm{a}}$ & $52.99^{a, b}$ & $50.68^{\mathrm{B}, \mathrm{a} b, \mathrm{c}}$ & $49.91^{\mathrm{A}, \mathrm{b}, \mathrm{c}}$ & $48.97^{\mathrm{B}, \mathrm{c}}$ & $50.05^{\mathrm{A}, \mathrm{b}, \mathrm{c}}$ \\
\hline Defender & $52.66^{\mathrm{A}, \mathrm{B}, \mathrm{a}}$ & $53.78^{a}$ & $54.59 \mathrm{~A}, \mathrm{a}$ & $46.92^{\mathrm{B}, \mathrm{b}}$ & $38.97^{C, c}$ & $34.54^{\mathrm{B}, \mathrm{d}}$ \\
\hline Feroz & $52.20^{\mathrm{B}, \mathrm{b}}$ & $53.15^{b}$ & $50.74^{\mathrm{B}, \mathrm{b}, \mathrm{c}}$ & $51.12^{\mathrm{A}, \mathrm{b}, \mathrm{c}}$ & $55.79 \mathrm{~A}, \mathrm{a}$ & $48.88^{\mathrm{A}, \mathrm{c}}$ \\
\hline \multicolumn{7}{|l|}{ Straw } \\
\hline Maximus & $65.93^{b}$ & $67.48^{\mathrm{b}}$ & $68.68^{b}$ & $66.50^{b}$ & $66.16^{b}$ & $72.59^{a}$ \\
\hline Defender & $67.29^{b, c}$ & $65.52^{c}$ & $68.62^{a, b}$ & $66.10^{c}$ & $70.49^{a}$ & $70.45^{a}$ \\
\hline Feroz & $66.38^{b}$ & $66.56^{b}$ & $64.74^{b}$ & $66.29^{b}$ & $71.19^{a}$ & $69.59^{a}$ \\
\hline
\end{tabular}

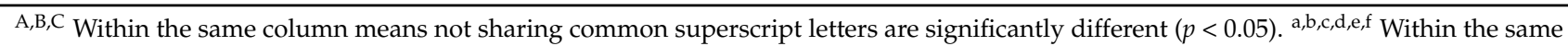
row means not sharing common superscript letters are significantly different $(p<0.05) \cdot \mathbf{x}=$ days after emergency (DAE). Straw $=$ vegetative fraction without the presence of grains.

The lowest ADF contents of the stems for the Maximus and Defender hybrids were observed in stage R3, while for Feroz the difference was only in R6 (Table 4). In the R1 stage there was no difference among the hybrids, in the other stages, the Maximus hybrid showed the lowest ADF content of stalk, except for the R6 stage where it did not differ from the Feroz hybrid.

The ADF content of the husk increased as the maturation progressed for the three hybrids. These differences among phases were quite evident in Maximus, with significant differences $(p<0.05)$ detected among all stages. The hybrids differed only in the initial three stages, with the highest values recorded for Feroz, along with Defender in R3. Similar data were recorded for the cobs.

The advancement of the reproductive stages resulted in a decrease in the whole plant ADF content for all the hybrids, with more expressive differences between R4 and R5 (stages with no difference among the hybrids). Regarding the straw, the data for each hybrid followed a similar behavior observed for the stems, with an emphasis on Maximus, which had the highest value in the R6 stage.

The ADL concentration of the stems did not differ among the maturity stages for any hybrid, but when a difference among them was presented, the lowest contents were observed for Maximus (Table 5). In leaves, the ADL content behaved distinctly differently for each of the hybrids. The Feroz hybrid had the highest ADL content in R1 (9.25\%), and together with the Defender hybrid had the highest content in R2 (8.07 and 8.98\%, respectively), while in R3 and R4 the hybrid Defender had the highest ADL content (11.21 and $10.41 \%$, respectively). In R5 and R6 there was no difference among hybrids. Unlike in 
the leaves, in husk, the highest values observed were in the Maximus hybrid in R3 and R5 (10.30 and $10.52 \%$, respectively).

Table 4. Acid detergent fiber (\% DM) of the whole plant and the fractions of three maize hybrids harvested at the beginning of the six reproductive stages of maturity.

\begin{tabular}{|c|c|c|c|c|c|c|}
\hline \multirow{2}{*}{ Fraction/Hybrid } & \multicolumn{6}{|c|}{ Phenological Stage } \\
\hline & R1 & $\mathbf{R} 2$ & R3 & $\mathbf{R} 4$ & R5 & R6 \\
\hline \multicolumn{7}{|l|}{ Stem } \\
\hline Maximus & $46.92^{\mathrm{a}}$ & $46.28^{\mathrm{B}, \mathrm{a}, \mathrm{b}}$ & $41.64^{\mathrm{B}, \mathrm{c}}$ & $44.15^{\mathrm{B}, \mathrm{b}}$ & $45.76^{\mathrm{C}, \mathrm{a}, \mathrm{b}}$ & $45.83^{\mathrm{B}, \mathrm{a}, \mathrm{b}}$ \\
\hline Defender & $49.50^{c, d}$ & $48.35^{\mathrm{A}, \mathrm{B}, \mathrm{c}, \mathrm{d}}$ & $47.49^{\mathrm{A}, \mathrm{d}}$ & $50.98^{\mathrm{A}, \mathrm{b}, \mathrm{c}}$ & $52.83^{\mathrm{A}, \mathrm{a}, \mathrm{b}}$ & $54.82 \mathrm{~A}, \mathrm{a}$ \\
\hline Feroz & $48.55^{\mathrm{a}}$ & $49.79 \mathrm{~A}, \mathrm{a}$ & $49.35^{\mathrm{A}, \mathrm{a}}$ & $48.64^{\mathrm{A}, \mathrm{a}}$ & $48.10^{\mathrm{B}, \mathrm{a}}$ & $43.76^{\mathrm{B}, \mathrm{b}}$ \\
\hline \multicolumn{7}{|l|}{ Leaves } \\
\hline Maximus & 33.12 & 35.03 & 32.85 & 32.80 & 33.45 & 33.56 \\
\hline Defender & 33.52 & 35.14 & 34.10 & 33.16 & 34.80 & 34.31 \\
\hline Feroz & 35.70 & 35.43 & 35.12 & 35.46 & 34.16 & 35.51 \\
\hline \multicolumn{7}{|l|}{ Husk } \\
\hline Maximus & $31.73^{\mathrm{B}, \mathrm{f}}$ & $32.66^{\mathrm{B}, \mathrm{e}}$ & $33.49^{\mathrm{B}, \mathrm{d}}$ & $37.24^{c}$ & $38.60^{b}$ & $40.20^{\mathrm{a}}$ \\
\hline Defender & $23.24^{C, d}$ & $31.95^{\mathrm{B}, \mathrm{c}}$ & $33.73^{\mathrm{A}, \mathrm{b}}$ & $34.36^{b}$ & $38.93^{a}$ & $41.80^{\mathrm{a}}$ \\
\hline Feroz & $32.21^{\mathrm{A}, \mathrm{c}}$ & $33.94^{\mathrm{A}, \mathrm{c}}$ & $32.98^{\mathrm{A}, \mathrm{b}}$ & $35.31^{b}$ & $39.31^{\mathrm{a}}$ & $41.11^{\mathrm{a}}$ \\
\hline \multicolumn{7}{|l|}{ Cob } \\
\hline Maximus & - & $22.11^{\mathrm{B}, \mathrm{e}}$ & $35.01^{B, d}$ & $38.18^{c}$ & $42.25^{b}$ & $45.20^{\mathrm{A}, \mathrm{a}}$ \\
\hline Defender & - & $23.42^{\mathrm{A}, \mathrm{d}}$ & $34.94^{\mathrm{B}, \mathrm{c}}$ & $37.67^{b}$ & $41.12^{\mathrm{a}}$ & $42.92^{\mathrm{B}, \mathrm{a}}$ \\
\hline Feroz & - & $20.36^{C, d}$ & $38.03^{\mathrm{A}, \mathrm{c}}$ & $38.41^{c}$ & $43.43^{b}$ & $46.08 \mathrm{~A}, \mathrm{a}$ \\
\hline \multicolumn{7}{|l|}{ Whole plant } \\
\hline Maximus & $33.21^{\mathrm{a}}$ & $33.09 \mathrm{~B}, \mathrm{a}$ & $28.93^{\mathrm{B}, \mathrm{b}}$ & $28.24^{b}$ & $21.70^{c}$ & $20.40^{\mathrm{A}, \mathrm{c}}$ \\
\hline Defender & $32.37^{\mathrm{a}, \mathrm{b}}$ & $34.56^{\mathrm{A}, \mathrm{a}}$ & $32.31^{\mathrm{A}, \mathrm{b}}$ & $26.74^{\mathrm{c}}$ & $21.58^{\mathrm{d}}$ & $17.21^{\mathrm{B}, \mathrm{e}}$ \\
\hline Feroz & $32.54^{\mathrm{a}}$ & $32.14^{\mathrm{B}, \mathrm{a}, \mathrm{b}}$ & $31.75^{\mathrm{A}, \mathrm{a}, \mathrm{b}}$ & $28.01^{b}$ & $21.96^{c}$ & $18.09 \mathrm{~A}, \mathrm{~B}, \mathrm{c}$ \\
\hline \multicolumn{7}{|l|}{ Straw } \\
\hline Maximus & $42.66^{b, c}$ & $44.10^{\mathrm{a}, \mathrm{b}}$ & $40.93^{\mathrm{A}, \mathrm{c}}$ & $42.05^{\mathrm{A}, \mathrm{b}, \mathrm{c}}$ & $41.12^{\mathrm{c}}$ & $46.03^{\mathrm{A}, \mathrm{a}}$ \\
\hline Defender & $43.15^{\mathrm{a}}$ & $41.07^{b}$ & $43.19^{\mathrm{A}, \mathrm{a}}$ & 38.69 B,c & $42.73^{\mathrm{a}, \mathrm{b}}$ & $42.75^{\mathrm{B}, \mathrm{a}, \mathrm{b}}$ \\
\hline Feroz & $43.92^{\mathrm{a}}$ & $42.92^{a}$ & $37.91^{\mathrm{B}, \mathrm{b}}$ & $41.35^{\mathrm{A}, \mathrm{a}}$ & $41.46^{\mathrm{a}}$ & $42.26^{\mathrm{B}, \mathrm{a}}$ \\
\hline
\end{tabular}

With the highest contents of ADL in the cobs $(p<0.05)$, the Maximus hybrid showed the highest concentration in stage R2, while the contents at the other stages exhibited an increasing trend with the advancement of maturation. For whole plants, there was no difference among the hybrids. However, the decrease in ADL concentration was less pronounced in the initial four stages and became more pronounced in the following two stages.

The Maximus hybrid showed the lowest ADL values for straw in stages R1 $(p<0.05)$, although there was an increase up to R5 in this compound. The ADL content in the Feroz hybrid varied between $8.31 \%$ and $9.39 \%$; this variation occurred specifically between the two final stages. The ADL content in the Defender hybrid did not differ among stages.

Defender and Feroz hybrids showed a higher concentration of hemicellulose in the stems at all stages compared to Maximus $(p<0.05)$, which varied in hemicellulose concentration from $63.11 \%$ in R3 to $67.39 \%$ in R5 (Table 6). The Maximus hybrid also showed the lowest hemicellulose values in their leaves in the initial four stages (R1-R4), with no differences from the Defender hybrid in R1 and R4. Again, the hemicellulose concentration in the leaves of Defender hybrid did not differ among stages. 
Table 5. Acid detergent lignin (\% DM) of the whole plant and the fractions of three maize hybrids harvested at the beginning of the six reproductive stages of maturity.

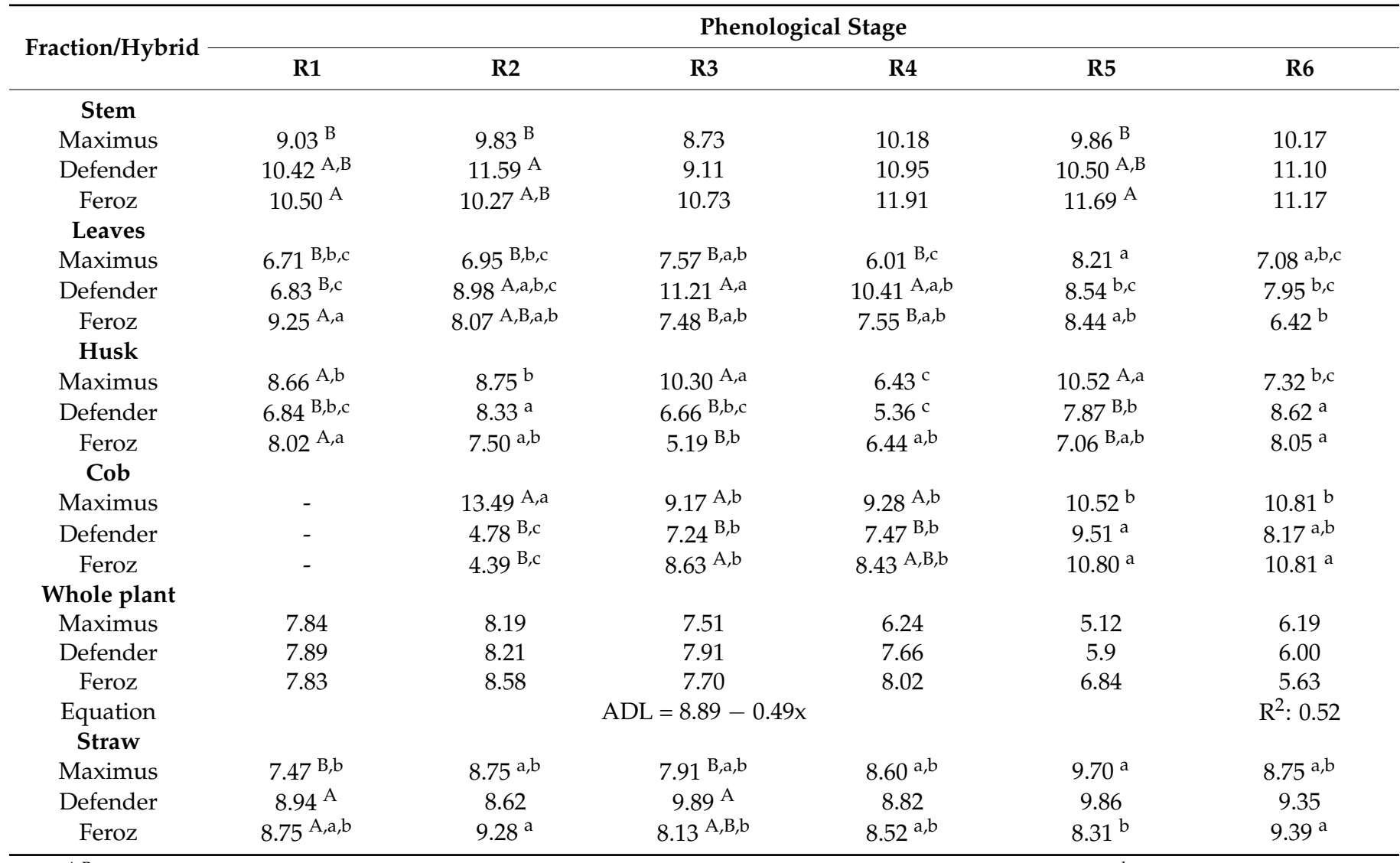

$\mathrm{A}, \mathrm{B}$ Within the same column means not sharing common superscript letters are significantly different $(p<0.05)$. $\mathrm{a}, \mathrm{b}, \mathrm{c}$ Within the same row means not sharing common superscript letters are significantly different $(p<0.05) . \mathbf{x}=$ days after emergency (DAE). Straw $=$ vegetative fraction without the presence of grains.

The Maximus hybrid had the highest values in R1, with a linear decrease during maturation. The concentration of hemicellulose in the Defender hybrid increased in the husk with the advancement of maturity. For the cobs, the concentration of hemicellulose in Maximus increased with the passing of the stages, which decreased in Defender.

The concentration of hemicellulose in the whole plant was higher in the Defender hybrid in the final two stages, with no differences between Maximus and Feroz. In general, there was a decrease in hemicellulose content with the advancement of the reproductive stage of all three hybrids. Similar, but less expressive, behavior was observed for the straw, where the hybrids differed in R4 and R6, with Feroz and Maximus presenting the greatest concentration in R4, and Maximus presenting the greatest concentration in R6.

Figure 1 shows that the maturation stage had a strong effect on milk production, as estimated by the Milk2006 model, either in kilograms of milk per ton of DM or in kilograms of milk per hectare, with points being grouped by maturation stage and no evidence of superiority for any hybrid. 
Table 6. Hemicellulose (\% of NDF) of the whole plant and the fractions of three maize hybrids harvested at the beginning of the six reproductive stages of maturity.

\begin{tabular}{|c|c|c|c|c|c|c|}
\hline \multirow{2}{*}{ Fraction/Hybrid } & \multicolumn{6}{|c|}{ Phenological Stage } \\
\hline & R1 & $\mathbf{R} 2$ & R3 & R4 & R5 & R6 \\
\hline \multicolumn{7}{|l|}{ Stem } \\
\hline Maximus & $64.21^{\mathrm{B}, \mathrm{b}, \mathrm{c}}$ & $64.62^{\mathrm{B}, \mathrm{b}, \mathrm{c}}$ & $63.11^{\mathrm{B}, \mathrm{c}}$ & $65.46^{\mathrm{B}, \mathrm{a}, \mathrm{b}, \mathrm{c}}$ & $67.39^{\mathrm{B}, \mathrm{a}}$ & $66.82^{\mathrm{B}, \mathrm{a}, \mathrm{b}}$ \\
\hline Defender & $70.04^{\mathrm{A}}$ & $69.71^{\mathrm{A}}$ & $70.90^{\mathrm{A}}$ & $72.56^{\mathrm{A}}$ & $73.28^{\mathrm{A}}$ & $72.83^{\mathrm{A}}$ \\
\hline Feroz & $68.16^{\mathrm{A}}$ & $70.49^{\mathrm{A}}$ & $70.74^{\mathrm{A}}$ & $71.08^{\mathrm{A}}$ & $71.04^{\mathrm{A}}$ & $70.02^{\mathrm{A}}$ \\
\hline \multicolumn{7}{|l|}{ Leaves } \\
\hline Maximus & $50.70^{\mathrm{B}, \mathrm{a}, \mathrm{b}}$ & $50.08^{\mathrm{B}, \mathrm{a}, \mathrm{b}}$ & $48.36^{\mathrm{B}, \mathrm{b}}$ & $49.64^{\mathrm{B}, \mathrm{a}, \mathrm{b}}$ & $51.67^{\mathrm{a}}$ & $51.99^{\mathrm{a}}$ \\
\hline Defender & $53.34^{\mathrm{B}}$ & $52.98^{\mathrm{A}}$ & $54.11^{\mathrm{A}}$ & 51.97 A,B & 54.46 & 53.09 \\
\hline Feroz & $56.34^{\mathrm{A}, \mathrm{a}}$ & $54.03^{A, a, b}$ & $54.37^{\mathrm{A}, \mathrm{a}, \mathrm{b}}$ & $54.21^{\mathrm{A}, \mathrm{a}, \mathrm{b}}$ & $52.49^{b}$ & $54.55^{\mathrm{a}, \mathrm{b}}$ \\
\hline \multicolumn{7}{|l|}{ Husk } \\
\hline Maximus & $55.77^{\mathrm{A}, \mathrm{a}}$ & $53.33^{b}$ & $52.18^{\mathrm{A}, \mathrm{b}, \mathrm{c}, \mathrm{d}}$ & $53.08^{\mathrm{A}, \mathrm{b}, \mathrm{c}}$ & $50.55^{d}$ & $51.00^{c, d}$ \\
\hline Defender & $48.48^{\mathrm{B}, \mathrm{c}}$ & $52.56^{a, b}$ & $49.79^{B, b, c}$ & $50.12^{\mathrm{B}, \mathrm{a}, \mathrm{b}, \mathrm{c}}$ & $50.54^{\mathrm{a}, \mathrm{b}}$ & $53.38^{a}$ \\
\hline $\begin{array}{c}\text { Feroz } \\
\text { Cob }\end{array}$ & $51.43^{\mathrm{B}, \mathrm{a}, \mathrm{b}}$ & $53.59^{a}$ & $48.44^{\mathrm{B}, \mathrm{c}}$ & $50.48^{\mathrm{B}, \mathrm{b}, \mathrm{c}}$ & $50.51^{b, c}$ & $52.84^{\mathrm{a}, \mathrm{b}}$ \\
\hline Maximus & - & $48.88^{\mathrm{C}, \mathrm{c}}$ & $52.64^{\mathrm{B}, \mathrm{b}}$ & $54.48^{\mathrm{a}, \mathrm{b}}$ & $55.58^{\mathrm{a}, \mathrm{b}}$ & $56.25^{\mathrm{a}}$ \\
\hline Defender & - & $65.03^{\mathrm{A}, \mathrm{a}}$ & $55.46^{\mathrm{A}, \mathrm{b}}$ & $54.47^{\mathrm{b}}$ & $55.42^{b}$ & $54.75^{\mathrm{b}}$ \\
\hline Feroz & - & $57.75^{\mathrm{B}}$ & $54.35^{\mathrm{A}, \mathrm{B}}$ & 54.27 & 55.92 & 56.33 \\
\hline \multicolumn{7}{|l|}{ Whole plant } \\
\hline Maximus & $62.03^{\mathrm{a}}$ & $62.44^{\mathrm{a}}$ & $57.11^{\mathrm{b}}$ & $56.59^{b}$ & $44.35^{\mathrm{B}, \mathrm{c}}$ & $40.30^{\mathrm{B}, \mathrm{d}}$ \\
\hline Defender & $61.48^{\mathrm{a}}$ & $61.26^{\mathrm{a}}$ & $59.19^{b}$ & $56.98^{c}$ & $55.36^{\mathrm{A}, \mathrm{c}}$ & 49.79 A,d \\
\hline Feroz & $62.34^{\mathrm{a}}$ & $60.47^{\mathrm{a}}$ & $62.60^{a}$ & $54.79^{a}$ & $38.59 \mathrm{~B}, \mathrm{~b}$ & $37.03^{B, b}$ \\
\hline \multicolumn{7}{|l|}{ Straw } \\
\hline Maximus & $64.72^{a, b}$ & $65.35^{a}$ & $59.63^{b}$ & $64.55^{\mathrm{A}, \mathrm{a}, \mathrm{b}}$ & $61.90^{\mathrm{a}, \mathrm{b}}$ & $63.40^{\mathrm{A}, \mathrm{a}, \mathrm{b}}$ \\
\hline Defender & $64.13^{\mathrm{a}}$ & $62.68^{a, b}$ & $62.95^{\mathrm{a}, \mathrm{b}}$ & $58.53^{\mathrm{B}, \mathrm{c}}$ & $60.63^{b, c}$ & $60.69^{B, b, c}$ \\
\hline Feroz & $66.17^{\mathrm{a}}$ & $64.46^{\mathrm{a}, \mathrm{b}}$ & $58.55^{\mathrm{d}}$ & $62.38^{\mathrm{A}, \mathrm{b}, \mathrm{c}}$ & $58.24^{\mathrm{d}}$ & $60.72^{B, c, d}$ \\
\hline
\end{tabular}

$\mathrm{A}, \mathrm{B}, \mathrm{C}$ Within the same column means not sharing common superscript letters are significantly different $(p<0.05)$. ${ }^{\mathrm{a}, \mathrm{b}, \mathrm{c}, \mathrm{d}}$ Within the same row means not sharing common superscript letters are significantly different $(p<0.05)$. Straw = vegetative fraction without the presence of grains.

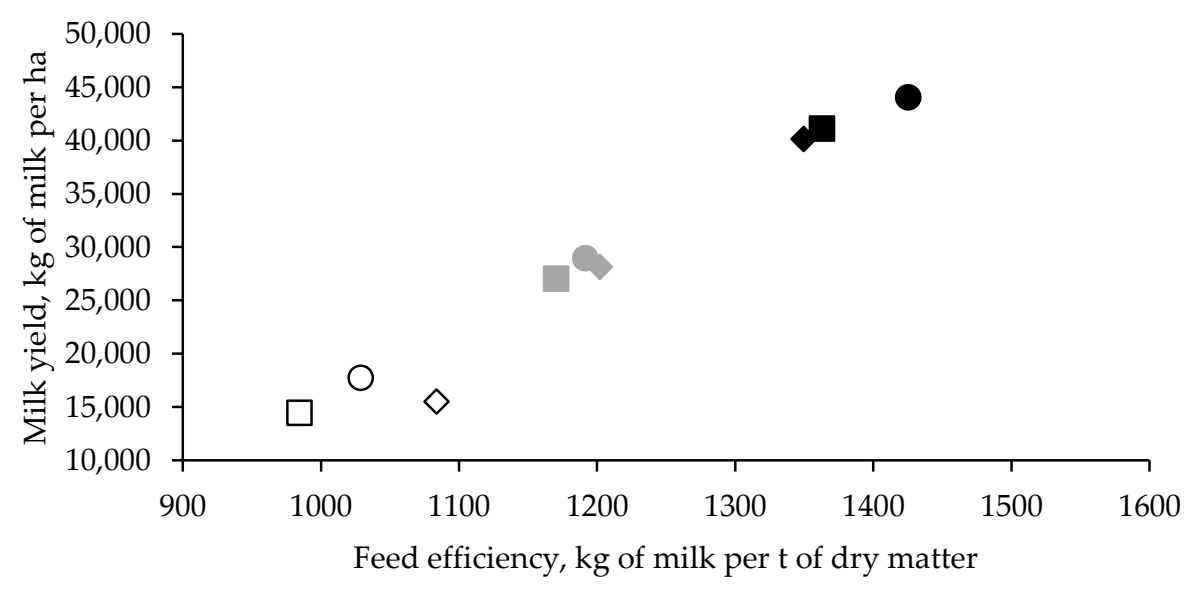

Figure 1. Estimation of milk production through Milk 2006 of the Maximus (•); Defender ( $\mathbf{\square})$; and Feroz $(\checkmark)$ hybrids in three harvest stages: R4 (white); R5 (grey); and R6 (black).

\section{Discussion}

First of all, we emphasize that this study was conducted in a single year and location, and therefore, for data interpretation, this fact must be taken into account.

The reduction in crude protein content in response to the advancement of maturation in our study was expected and is in accordance with several other reports [12,21]. Hetta [12] and Schittenhelm [21] also did not observe significant differences among the evaluated 
hybrids. Despite being nutritionally less favorable mainly due to the low starch content, it seems that the early harvest results in lower production of methane by cattle due to the lower yield of this compound with proteins when compared to carbohydrates [22]. On the other hand, the maturity advance with starch accumulation in the grain can reduce the methane emission expressed in relation to the carcass gain [23].

During the initial reproductive phase, there is an accumulation of crude protein in several fractions of the plant, and this accumulation is promoted by the specific accelerated photosynthetic rate during this stage to supply the requirements of the reproductive structure [5]. In the absence of environmental stress, there is a decrease in the protein concentration of whole plants, driven mainly by the stems and leaves due to both translocation to the grain [12] and replacement of the nitrogenous compounds of these fractions by structural components to meet the momentary needs of the plant [5]. Wojcieszak et al. [24] specifically proved that advancement in maturation strengthens the relationship between carbon and nitrogen in the ear but weaken the leaves and stems due to the phenomenon of senescence. Despite the CP losses observed for husk and cob, there is an increase in the deposit of protein matrix in the grains, equaling the $\mathrm{CP}$ content of snaplage [8] and earlage [13] at various stages.

The hybrid Maximus showed the highest $\mathrm{CP}$ content in the leaves at stages $\mathrm{R} 1$ and R2, and with the Defender hybrid, the highest CP contents in R3, R4 and R6. In the R5 stage, the hybrid Feroz had the highest CP content among them (Table 2). Differences in $\mathrm{CP}$ contents between one hybrid and another may indicate that such hybrid experiences fewer impacts due to late harvests, either as whole plant silage, earlage or snaplage, as there seems to be a longer active photosynthesis stage in this type of hybrid due to the increased presence of chlorophyll-protein complexes [25].

The chemical differences observed for the husk and cobs must be taken into account, especially when the purpose is the production of earlage or snaplage [26], with an approximate representation of $20-30 \%$ in these components [27]. Arriola et al. [25] also observed differences in the amount of protein between ears of different hybrids, with no differences between grains, suggesting that husk and cobs can considerably affect the final quality of the product. However, Gusmão et al. [8] did not observe differences in CP content in husk and cob among maturity stages, but the differences in the $\mathrm{CP}$ content of grains impacted snaplage quality.

Tolera et al. [28] also mentioned the importance of maize harvest residue in studies carried out in Africa and Asia, and also exposed chemical differences that may be due to the type of cultivated hybrid. It was in the most advanced stage (R6) that we observed differences in the crude protein of straw among the hybrids, with a variation that exceeds one percentage unit.

The whole-plant NDF contents were inconsistent among hybrids in the different maturation phases, similar to those reported by Ferraretto et al. [4] in a study evaluating hybrids during two different harvest stages. In general, excluding the effects of the hybrids, we observed a decrease in the NDF content of whole plants with the advancement of maturation due to the increased proportion of the grain in the plant [3]. This is confirmed when contrasted with the NDF values of the whole plants and the values of the plants without grain (straw) in the last two stages (Table 3), because in plants without grain, the NDF content has a constant linear increase, and in whole plants, we observe the lowest values in these stages, where there is greater proportion of grains.

Even though we observed high NDF values for the whole plants in the initial stages, Der Bedrosian et al. [3] stated that there is a higher concentration of soluble fiber in this early stage of the plant, and a relatively high proportion of it is concentrated in the leaves. The results of Macome et al. [5] are in agreement, as they state that NDF digestibility is higher in the early stages than at the later stages. This becomes even more important when seen from the perspective that NDF is among the compounds with the greatest presence in the plant and the greatest nutritional effects on the resulting silage [29]. 
In general, there was a reduction in the NDF content of the stalk between the initial and intermediates stages (R1 and R2 to R3 and R4), contrary to the continuous increase that we expected for this variable. Phipps et al. [30] suggested that during the maturation of maize there is a change in the carbohydrates that make up the NDF for the formation of starch in the grains. Supporting this idea, Macome et al. [5] also pointed out the occurrence of this phenomenon in the early stages, with a tendency to maintain or increase the NDF after stabilizing the grain formation, similar to what occurred in our study.

It is consistent that there is an increase in NDF content in the leaves with the advancement of maturation [12], and although other studies have also shown nonlinear trends similar to our data [31], we believe that this alleged behavior observed for the NDF content in the leaves may be linked to losses due to decomposition of the leaves of the bass; therefore, these data at the end of maturation should be interpreted with caution, even if they are very close to those reported in the literature. We emphasize that the NDF content was analyzed without sodium sulfite, and this may keep protein residues bound to the cell-wall, increasing the values.

The NDF content in the husk and cobs increased linearly as a result of advancing maturation. Hetta et al. [12] found a correlation of 0.712 between an increase in the dry matter content and the NDF content of cobs. The same authors emphasized that the increase in NDF in husk occurs due to the lignification and transport of available carbohydrates in the form of sugars for grain filling, as previously described for leaf senescence. Among ear components, the cob and husk have a lower proportion of non-fiber carbohydrates and, as maturity advanced, a lower concentration of soluble carbohydrates, as fructose and glucose decrease and, consequently, the NDF concentration increase in these components [25]. Furthermore, with greater maturity, the NDFD decreases for both [8].

The reduction in the concentration of ADF in whole plants is in line with the trend observed in numerous studies $[5,32,33]$. This reduction is essentially provided by the considerable increase in the involvement of the grain in the plant $[25,32]$, but it does not mean qualitative improvements in the vegetative fraction [28], even despite our observations of linear decreases in lignin content of the whole plants with advancing maturation. What we affirm can be proven by observing that the proportion of ADF and ADL in straw differs. In general, dry matter digestibility is reduced due to lignification and an increase in cell wall thickness [12]. The phenomenon of reduced digestibility in the cell wall of maize plants as a function of maturity has been described in the results of experiments both in vitro [34] and in vivo [35].

It is important to differentiate what happens to lignin content during maize maturity development. First, and what is shown in books of plant physiology, is that the advancement of maturity leads to an increase in the concentration of lignin, and this is true if we analyze the maturity beginning at plant emergence. However, here, we analyzed the lignin content between two specific points, where there is a rapid and considerable increase in grains. Irlbeck et al. [36] also reported that a delay of 28 days after physiological maturity considerably increased the proportion of grains in the plant, reducing leaf yields. The ADL values of the leaves described by Zeoula et al. [31] are close to those seen in this study, but unlike us, the authors found differences among the evaluated hybrids.

Schittenhelm [21] evaluated the components of the NDF of maize hybrids at different harvest times and observed less associative behavior among the hybrids and the harvest time for lignin but observed similarities among the hybrids in terms of hemicellulose until the later maturation stages. As maturation advances, the number of covalent bonds between lignin and hemicellulose increase [31], reducing the digestibility of the material and therefore leaving only hemicellulose content for judging whether or not harvest is a viable option. On the other hand, with a relatively high concentration of soluble carbohydrates in plant leaves and stems, it is important to observe the concentration of hemicellulose in husk and cobs when the production of earlage or snaplage is the aim, since this has the potential to assist in the production of acids during the silage fermentation process [26]. 
Variations in the content of hemicellulose and lignin have been reported among the main components of maize plants in studies that aimed to evaluate comparisons for bioenergy production. Mullen et al. [37] reported 38\% hemicellulose and 3\% lignin for ears, Wang et al. [38] reported 23\% hemicellulose and 7\% lignin for leaves and Luo et al. [39] reported $71 \%$ hemicellulose and $18 \%$ lignin for stems. Therefore, when choosing a maize hybrid for silage, earlage or snaplage, the morphological composition of the hybrid must be judged according to its purpose. The morphological data of the hybrids evaluated in this study can be found in Horst et al. [17]

For reasons that are still relatively unexplored, it seems that the stems of earlymaturing hybrids are less lignified than those of later-maturing hybrids [3,31]. Thus, among the hybrids evaluated in the present study, Maximus has the longest maturation period and presented ADL contents in the stalk ranging from 8.73 to $10.18 \%$.

As mentioned in Horst et al. [40], slight variations in fiber quality may not be sufficient to influence the estimation of the milk yield potential, whereas the gradual increase in the proportion of grains in plants with increasing maturity shows its importance. As the grain is the most energetic fraction, the most advanced stages showed the highest values for both milk yield and feed efficiency [41].

According to Johnson et al. [42] the yield of each hybrid should also be taken into account for decision making, as the differences found in the dry matter yield per area were balanced by the differences observed among hybrids when estimating the milk yield per hectare.

Overall, our results suggest that recommendations for harvesting based on the stage of maturation should be taken with caution and should account for the hybrid used. However, the choice of hybrid for silage production should be considered only after knowing its most opportune harvest time, considering that the effects on the estimated milk production are more reflective of the reproductive stage than the hybrids themselves. The trends observed for the whole plant do not always repeat what is observed in all fractions, especially in husk and cob. Therefore, earlages and snaplages must be made by looking closely at these fractions, as well as the grains.

\section{Conclusions}

The advancement in maturation reduces the protein content of whole plants, which is provided mainly by the reduction in leaves and stems. The content of NDF should be included among the main criteria analyzed for choosing the material to be grown, as it seems to experience greater effects in hybrid than does crude protein. Even with inconsistent differences among hybrids, the effects on the estimated milk production are more reflective of the harvest stage than the hybrid.

There seems to be no important distinction among hybrids for harvesting and use of straw. Despite the reduction in grain yield, an early harvest for earlage or snaplage can provide lower lignin content in husk and cob, as well as higher protein content in the husk, favoring the nutritional value of the vegetative fraction (husk and/or cob).

Author Contributions: Conceptualization, E.H.H., M.N. and S.L.; methodology, E.H.H., M.N. and S.L.; software, E.H.H.; validation, V.H.B.J. and S.L.; formal analysis, E.H.H. and S.L.; investigation, E.H.H.; resources, M.N. and S.L.; data curation, E.H.H. and V.H.B.J.; writing-original draft preparation, E.H.H.; writing—review and editing, M.N., V.H.B.J. and S.L.; visualization, S.L.; supervision, V.H.B.J., M.N. and S.L.; project administration, M.N., V.H.B.J. and S.L.; funding acquisition, E.H.H., and S.L. All authors have read and agreed to the published version of the manuscript.

Funding: This research received no external funding.

Institutional Review Board Statement: The study was conducted according to the guidelines of the Declaration of Helsinki, and approved by the Ethics Committee of Midwestern Parana State University-UNICENTRO (protocol code 002/2017, 27 May 2017).

Informed Consent Statement: Not applicable. 
Acknowledgments: Egon Henrique Horst thanks the Ministry of Education of Brazil (MEC) for funding under the scholarship through CAPES.

Conflicts of Interest: The authors declare no conflict of interest.

\section{References}

1. Ferraretto, L.F.; Shaver, R.D. Effects of whole-plant corn silage hybrid type on intake, digestion, ruminal fermentation, and lactation performance by dairy cows through a meta-analysis. J. Dairy Sci. 2015, 98, 2662-2675. [CrossRef]

2. Auerbach, H.; Weissbach, F. Quality of forage maize and maize silage-effects of growth stage on feeding value, fermentability, fermentation characteristics and effluent production potential. Landbauforsch. Voelkenrode Sonderh. 1999, 206, 159-178.

3. Der Bedrosian, M.C.; Nestor, K.E., Jr.; Kung, L., Jr. The effects of hybrid, maturity, and length of storage on the composition and nutritive value of corn silage. J. Dairy Sci. 2012, 95, 5115-5126. [CrossRef] [PubMed]

4. Ferraretto, L.F.; Crump, P.M.; Shaver, R.D. Effect of ensiling time and exogenous protease addition to whole-plant corn silage of various hybrids, maturities, and chop lengths on nitrogen fractions and ruminal in vitro starch digestibility. J. Dairy Sci. 2015, 98, 8869-8881. [CrossRef]

5. Macome, F.M.; Pellikaan, W.F.; Hendriks, W.H.; Dijkstra, J.; Hatew, B.; Schonewille, J.T.; Cone, J.W. In vitro gas and methane production of silages from whole-plant corn harvested at 4 different stages of maturity and a comparison with in vivo methane production. J. Dairy Sci. 2017, 100, 8895-8905. [CrossRef]

6. Ferraretto, L.F.; Shaver, R.D.; Lauer, J.G.; Brown, L.; Lutz, R.; Kennicker, J.; Taysom, D.M. Influence of plant population, maturity and ensiling time on fermentation profile, nitrogen fractions, and starch digestibility in earlage. J. Anim. Sci. 2016, 94, 300. [CrossRef]

7. Akins, M.S.; Shaver, R.D. Effect of corn snaplage on lactation performance by dairy cows. Prof. Anim. Sci. 2014, 30, 86-92. [CrossRef]

8. Gusmão, J.O.; Lima, L.M.; Ferraretto, L.F.; Casagrande, D.R.; Bernardes, T.F. Effects of hybrid and maturity on the conservation and nutritive value of snaplage. Anim. Feed Sci. Technol. 2021, 274, 114899. [CrossRef]

9. Hunter, R.B. Selection and evaluation procedures for whole-plant corn silage. Can. J. Plant Sci. 1978, 58, 661-678. [CrossRef]

10. Marton, C.; Kálmán, L.; Árendás, T.; Bónis, P.; Szieberth, D. Comparison of some methods for estimating vegetation periods in maize. Acta Agron. Hung. 2007, 55, 1-5. [CrossRef]

11. Argillier, O.; Méchin, V.; Barrière, Y. Inbred line evaluation and breeding for digestibility-related traits in forage maize. Crop Sci. 2000, 40, 1596-1600. [CrossRef]

12. Hetta, M.; Mussadiq, Z.; Gustavsson, A.M.; Swensson, C. Effects of hybrid and maturity on performance and nutritive characteristics of forage maize at high latitudes, estimated using the gas production technique. Anim. Feed Sci. Technol. 2012, 171, 20-30. [CrossRef]

13. Lardy, G.; Anderson, V. Harvesting, Storing, and Feeding Corn as Earlage; AS-1490; North Dakota State University Extension: Fargo, ND, USA, 2010.

14. Zhang, Y.; Ghaly, A.E.; Li, B. Physical properties of corn residues. Am. J. Biochem. Biotechnol. 2012, 8, 44-53. [CrossRef]

15. Chen, G.; Zheng, Z.; Yang, S.; Fang, C.; Zou, X.; Luo, Y. Experimental co-digestion of corn stalk and vermicompost to improve biogas production. Waste Manag. 2010, 30, 1834-1840. [CrossRef]

16. Ritchie, S.W.; Hanway, J.J.; Benson, G.O. Como a planta de milho se desenvolve. Inf. Agron. 2003, 103, 1-19.

17. Horst, E.H.; Bumbieris, V.H., Jr.; Neumann, M.; Souza, A.M.; Venancio, B.J.; Stadler, E.S., Jr.; Santos, L.C. Agronomic characteristics of maize hybrids (Zea mays, L.) at different maturity stages. Semin. Anim. Sci. 2020, 41, 2273-2284. [CrossRef]

18. AOAC-Association of Official Analytical Chemists. Official Methods of Analysis, 16th ed.; AOAC International: Washington, DC, USA, 1995.

19. Goering, H.K.; Van Soest, P.J. Forage Fiber Analysis: Apparatus Reagents, Procedures and Some Applications; Agricultural Handbook; Agricultural Research Service: Washington, DC, USA, 1970; pp. 1-20.

20. Shaver, R.D.; Lauer, J.G. Review of Wisconsin corn silage milk per ton models. J. Dairy Sci. 2006, 89, 282.

21. Schittenhelm, S. Chemical composition and methane yield of maize hybrids with contrasting maturity. Eur. J. Agron. 2008, 29, 72-79. [CrossRef]

22. Singh, S.; Kushwaha, B.P.; Nag, S.K.; Mishra, A.K.; Singh, A.; Anele, U.Y. In vitro ruminal fermentation, protein and carbohydrate fractionation, methane production and prediction of twelve commonly used Indian green forages. Anim. Feed Sci. Technol. 2012, 178, 2-11. [CrossRef]

23. McGeough, E.J.; O'Kiely, P.; Foley, P.A.; Hart, K.J.; Boland, T.M.; Kenny, D.A. Methane emissions, feed intake, and performance of finishing beef cattle offered maize silages harvested at 4 different stages of maturity. J. Anim. Sci. 2010, 88, 1479-1491. [CrossRef] [PubMed]

24. Wojcieszak, D.; Przybył, J.; Ratajczak, I.; Goliński, P.; Janczak, D.; Waśkiewicz, A.; Woźniak, M. Chemical composition of maize stover fraction versus methane yield and energy value in fermentation process. Energy 2020, 198, 117258. [CrossRef]

25. Arriola, K.G.; Kim, S.C.; Huisden, C.M.; Adesogan, A.T. Stay-green ranking and maturity of corn hybrids: 1 . Effects on dry matter yield, nutritional value, fermentation characteristics, and aerobic stability of silage hybrids in Florida. J. Dairy Sci. 2012, 95, 964-974. [CrossRef] [PubMed] 
26. Nigon, B.J.; Shinners, K.J.; Cook, D.E. Harvester modifications to alter composition and dry matter of corn-silage. Appl. Eng. Agric. 2016, 32, 157-167. [CrossRef]

27. Daniel, J.L.P.; Bernardes, T.F.; Jobim, C.C.; Schmidt, P.; Nussio, L.G. Production and utilization of silages in tropical areas with focus on Brazil. Grass Forage Sci. 2019, 74, 188-200. [CrossRef]

28. Tolera, A.; Sundstøl, F.; Said, A.N. The effect of stage of maturity on yield and quality of maize grain and stover. Anim. Feed Sci. Technol. 1998, 75, 157-168. [CrossRef]

29. Bernardes, T.F.; Daniel, J.L.P.; Adesogan, A.T.; McAllister, T.A.; Drouin, P.; Nussio, L.G.; Cai, Y. Silage review: Unique challenges of silages made in hot and cold regions. J. Dairy Sci. 2018, 101, 4001-4019. [CrossRef] [PubMed]

30. Phipps, R.H.; Sutton, J.D.; Beever, D.E.; Jones, A.K. The effect of crop maturity on the nutritional value of maize silage for lactating dairy cows. 3. Food intake and milk production. Anim. Sci. 2000, 71, 401-409. [CrossRef]

31. Zeoula, L.M.; Beleze, J.R.F.; Cecato, U.; Jobim, C.C.; Geron, L.J.V.; Maeda, E.M.; Falcão, A.J.D.S. Avaliação de cinco híbridos de milho (Zea mays, L.) em diferentes estágios de maturação: 3. Composição químico-bromatológica. Braz. J. Anim. Sci. 2003, 32, 556-566. [CrossRef]

32. Keady, T.W.J.; Kilpatrick, D.J.; Mayne, C.S.; Gordon, F.J. Effects of replacing grass silage with maize silages, differing in maturity, on performance and potential concentrate sparing effect of dairy cows offered two feed value grass silages. Livest. Sci. 2008, 119, 1-11. [CrossRef]

33. Rabelo, C.H.S.; Rezende, A.V.; Rabelo, F.H.S.; Nogueira, D.A.; Senedese, S.S.; Figueiredo Vieira, P.; Carvalho, A. Silagens de milho inoculadas microbiologicamente em diferentes estágios de maturidade: Perdas fermentativas, composição bromatológica e digestibilidade in vitro. Cienc. Rural 2014, 44, 368-373. [CrossRef]

34. Deaville, E.R.; Givens, D.I. Use of the automated gas production technique to determine the fermentation kinetics of carbohydrate fractions in maize silage. Anim. Feed Sci. Technol. 2001, 93, 205-215. [CrossRef]

35. Jensen, C.; Weisbjerg, M.R.; Nørgaard, P.; Hvelplund, T. Effect of maize silage maturity on site of starch and NDF digestion in lactating dairy cows. Anim. Feed Sci. Technol. 2005, 118, 279-294. [CrossRef]

36. Irlbeck, N.A.; Russell, J.R.; Hallauer, A.R.; Buxton, D.R. Nutritive value and ensiling characteristics of maize stover as influenced by hybrid maturity and generation, plant density and harvest date. Anim. Feed Sci. Technol. 1993, 41, 51-64. [CrossRef]

37. Mullen, C.A.; Boateng, A.A.; Goldberg, N.M.; Lima, I.M.; Laird, D.A.; Hicks, K.B. Bio-oil and bio-char production from corn cobs and stover by fast pyrolysis. Biomass Bioenergy 2010, 34, 67-74. [CrossRef]

38. Wang, T.; Yin, J.; Zheng, Z. Effects of chemical inhomogeneity of corn stalk on solvolysis liquefaction. Carbohydr. Polym. 2012, 87, 2638-2641. [CrossRef]

39. Luo, S.; Liu, C.; Xiao, B.; Xiao, L. A novel biomass pulverization technology. Renew. Energy 2011, 36, 578-582. [CrossRef]

40. Horst, E.H.; López, S.; Neumann, M.; Giráldez, F.J.; Bumbieris Junior, V.H. Effects of Hybrid and Grain Maturity Stage on the Ruminal Degradation and the Nutritive Value of Maize Forage for Silage. Agriculture 2020, 10, 251. [CrossRef]

41. Comino, L.; Tabacco, E.; Righi, F.; Revello-Chion, A.; Quarantelli, A.; Borreani, G. Effects of an inoculant containing a Lactobacillus buchneri that produces ferulate-esterase on fermentation products, aerobic stability, and fibre digestibility of maize silage harvested at different stages of maturity. Anim. Feed Sci. Technol. 2014, 198, 94-106. [CrossRef]

42. Johnson, L.M.; Harrison, J.H.; Davidson, D.; Swift, M.; Mahanna, W.C.; Shinners, K. Corn silage management II: Effects of hybrid, maturity, and mechanical processing on digestion and energy content. J. Dairy Sci. 2002, 85, 2913-2927. [CrossRef] 